\title{
Fibrinolysis and insulin sensitivity in imidapril and candesartan (FISIC study) recipients with hypertension
}

\author{
Roberto Fogari, Annalisa Zoppi, Sibilla AT Salvadeo, Amedeo Mugellini, Pierangelo Lazzari, Tara Santoro \\ and Giuseppe Derosa
}

The aim of this study was to evaluate the effects of imidapril and candesartan on fibrinolysis and insulin sensitivity in normoweight hypertensive patients. After a 2-week wash-out period, 61 patients with mild-to-moderate hypertension were randomized to imidapril or candesartan for 12 weeks. Blood pressure (BP), plasma tissue plasminogen activator (t-PA) and plasminogen activator inhibitor-1 (PAI-1) antigen activities were evaluated at baseline and during treatment. The patients underwent a euglycemic-hyperinsulinemic clamp (insulin sensitivity was evaluated as glucose infusion rate during the last $30 \mathrm{~min}$ ) and a desmopressin test (with desmopressin infusion in the brachial artery) to evaluate endothelial ability to release t-PA. Imidapril and candesartan induced similar systolic/diastolic BP reductions $(-16 / 12.6$ and $-16.1 / 12.2 \mathrm{~mm} \mathrm{Hg}$, respectively, $P<0.001$ vs. baseline). Imidapril increased glucose infusion rate $\left(+1.1 \mathrm{mg} \mathrm{min}^{-1}\right.$ per $\left.\mathrm{kg}, P<0.02\right)$, whereas candesartan did not change it. Both drugs decreased PAI-1 antigen activity after 4 weeks of treatment; subsequently, only the decreasing effect of imidapril was sustained throughout the 12 weeks, whereas candesartan increased PAI-1 activity at week $12(P<0.05$ vs. baseline, $P<0.01$ vs. imidapril). Activity of t-PA decreased with candesartan (from $0.48 \pm 0.16$ to $\left.0.43 \pm 0.14 \mathrm{IU} \mathrm{ml}^{-1}, P<0.05\right)$ but not with imidapril. Activity of $\mathrm{t}-\mathrm{PA}$ in response to desmopressin was increased more by imidapril $\left(+4.45 \mathrm{IU} \mathrm{ml}^{-1}\right)$ than by candesartan $\left(+2.73 \mathrm{IU} \mathrm{ml}^{-1}, P<0.01\right.$ vs. imidapril). These results indicate that in normoweight hypertensive patients, despite similar BP reduction, imidapril but not candesartan improved the fibrinolytic balance, suggesting that mechanisms other than Ang II inhibition, possibly including bradykinin-mediated effects on insulin sensitivity and endothelial function, may be responsible for these different effects.

Hypertension Research (2011) 34, 509-515; doi:10.1038/hr.2010.260; published online 23 December 2010

Keywords: candesartan; fibrinolysis; imidapril; insulin sensitivity

\section{INTRODUCTION}

A growing body of evidence indicates that the rennin-angiotensinaldosterone system, which has an important pathophysiological role in hypertension, can influence the balance of the fibrinolytic system by stimulating production of plasminogen activator inhibitor-1 (PAI-1) and by reducing tissue plasminogen activator (t-PA) production. ${ }^{1-3}$ angiotensin II (Ang II) induces synthesis of PAI-1 in cultured endothelial cells, ${ }^{4,5}$ murine brain astrocytes ${ }^{6}$ and vascular smooth muscle cells. ${ }^{4,7}$ In agreement with these in vitro results, infusion of Ang II into healthy volunteers and hypertensive subjects produces a rapid increase in circulating PAI- $1 .^{8}$ Aldosterone is another factor through which the rennin-angiotensin-aldosterone system may influence PAI-1 level, as demonstrated in vitro and in vivo. ${ }^{1,9}$ Because bradykinin increases the release of t-PA from endothelial cells, ${ }^{10,11}$ angiotensin converting enzyme (ACE), which degrades bradykinin and catalyzes the conversion of Ang I to Ang II, might contribute to the reduction in $\mathrm{t}-\mathrm{PA}$ production.
Clinical use of ACE inhibitors (ACE-Is) has been associated with a reduction in PAI- 1 in most of the trials. ${ }^{12-17}$ The effects of ACE-Is on $\mathrm{t}$-PA are more controversial, as some studies have shown increased $\mathrm{t}$ PA levels, ${ }^{18,19}$ other studies have reported decreased t-PA levels ${ }^{12,20}$ and still others have observed unchanged t-PA levels during ACE inhibition. ${ }^{13,21,22}$ One possible explanation for these contrasting findings might be that t-PA exists in several forms, including free active t-PA and t-PA bound to PAI-1 and other inhibitors. ${ }^{23}$ Moreover, the systemic levels of t-PA may not reflect the local profibrinolytic capacity in terms of availability of active t-PA at the organ level, which in turn depends on the magnitude of local t-PA release from the endothelium. ${ }^{24,25}$ Data on the effects of Ang II AT1 receptor blockers (ARBs) on fibrinolysis are even more controversial, with some studies showing a reduction in PAI-1 plasma level ${ }^{26-28}$ and others showing no effect. ${ }^{19,29-32}$ Reasons for such different findings might be because of differences in experimental models, study population characteristics, duration of treatment and possible methodological bias. Some direct 
comparisons on the effects of ACE-Is and ARBs on plasma PAI- 1 and $\mathrm{t}$-PA have been performed, and again the results were controversial: ${ }^{33-38}$ Some studies have shown that both ACE inhibition and AT1 antagonism were associated with a significant improvement in plasma fibrinolysis, ${ }^{34}$ whereas others have observed a decrease in PAI-1 and/ or an increase in t-PA with ACE-Is but not with ARBs. ${ }^{33,35-37}$ Only a few studies have reported an improvement of fibrinolytic balance with ARBs. ${ }^{38}$

With this background, the present study was undertaken to compare the effects of 12-week treatment with the ACE-I imidapril and the ARB candesartan on plasma PAI- 1 antigen level and activity and on plasma t-PA activity level in a homogeneous population of normoweight (body mass index $(\mathrm{BMI}) \leqslant 25 \mathrm{~kg} \mathrm{~m}^{-2}$ ) hypertensive patients. The capacity for acute t-PA release from vascular endothelium before and after treatment with the two drugs has also been assessed through arterial infusion of desmopressin. ${ }^{39,40}$ In vitro studies show that proinsulin and insulin stimulate the synthesis of PAI-1 in human hepatocytes and endothelial cells, ${ }^{41,42}$ which has also been confirmed in vivo. ${ }^{43}$ Additionally, insulin resistance with resulting hyperinsulinemia is frequently accompanied by increased PAI-1 level. ${ }^{44-46}$ Owing to this close relationship between insulin sensitivity and the fibrinolytic system, the effects of imidapril and candesartan on insulin sensitivity, as assessed by euglycemic-hyperinsulinemic clamp, ${ }^{47}$ were evaluated.

\section{METHODS}

\section{Study design}

This was a 12-week, prospective, randomized, open-label, blinded-endpoint (PROBE), ${ }^{48}$ parallel group study with two treatment arms.

\section{Study population}

Male and female normoweight outpatients, aged 18-65 years, with mild-tomoderate essential hypertension (defined as sitting systolic $\mathrm{BP} \geqslant 140$ and $<180 \mathrm{~mm} \mathrm{Hg}$ and sitting diastolic BP $\geqslant 90$ and $<105 \mathrm{~mm} \mathrm{Hg}$ after a 2 week run-in wash-out period) associated with at least one other cardiovascular risk factor (smoking, echocardiographic left ventricular hypertrophy, male with age $>55$ years, family history of cardiovascular disease or carotid intima-media thickness ratio $<0.9$ ) were considered for enrollment.

Patients with secondary hypertension, BMI $>25 \mathrm{~kg} \mathrm{~m}^{-2}$, creatinine clearance $<80 \mathrm{ml} \mathrm{min}^{-1}$, total cholesterol $\geqslant 250 \mathrm{mg} \mathrm{dl}^{-1}$, diabetes mellitus, history of myocardial infarction or stroke within 6 months before the study, congestive heart failure or any severe diseases likely to interfere with the conduction of the study were excluded, as were those with known contraindications or intolerance to ARB or ACE-Is.

\section{Ethics}

The study was performed in accordance with the Declaration of Helsinki and its amendments, and all patients gave their written informed consent to participate in the study at the time of enrollment.

\section{Study protocol}

After a 2-week run-in wash-out period, patients fulfilling the inclusion criteria were randomized to $5 \mathrm{mg}$ imidapril or $8 \mathrm{mg}$ candesartan, both given once a day in the morning (at approximately $0800 \mathrm{~h}$ ) for 12 weeks. After 2, 4 and 8 weeks, a dose titration consisting of a progressively increasing amount of imidapril to $20 \mathrm{mg}$ or candesartan to $32 \mathrm{mg}$ was permitted in non-responder patients (systolic $\mathrm{BP} \geqslant 140 \mathrm{~mm} \mathrm{Hg}$ and/or diastolic $\mathrm{BP} \geqslant 90 \mathrm{~mm} \mathrm{Hg}$ ). The doses of the two drugs were chosen to be equipotent with respect to blood pressure (BP) lowering. From the time of enrollment until the completion of the study, all participants maintained their usual diet and level of physical activity and avoided changes in body weight. No concomitant medication was allowed. Medication compliance was assessed by a residual capsule count at each visit.
Blood pressure, PAI-1 antigen level and activity and t-PA activity were evaluated at the end of the wash-out period and after 1, 2, 4, 8 and 12 weeks of treatment, whereas fasting plasma glucose, fasting plasma insulin, insulin sensitivity and the t-PA activity response to desmopressin were evaluated only at the end of the wash-out period and of each treatment period.

The BP measurements were obtained from each patient (right arm) in the seated position by using a standard mercury sphygmomanometer (Korotkoff I and V) with a cuff of appropriate size. Measurements were taken in the morning before daily drug intake (that is, $24 \mathrm{~h}$ after dosing, at trough) and after the subject had rested $10 \mathrm{~min}$ in a quiet room. Three successive BP readings were obtained at 1-min intervals and averaged.

\section{Evaluation of fibrinolytic parameters}

Venous blood was drawn from an antecubital vein for blood sampling at the same hour in the morning, approximately between 0800 and $0900 \mathrm{~h}$, because it was confirmed that PAI-1 concentration peaked during this period in the preliminary experiments. Blood samples were collected on ice and centrifuged immediately at $0{ }^{\circ} \mathrm{C}$ for $20 \mathrm{~min}$. All plasma or serum samples were separated and stored at $-70{ }^{\circ} \mathrm{C}$ until assaying. Blood for measuring PAI-1 antigen was collected in Vacutainer tubes containing $0.105 \mathrm{mmoll}^{-1}$ acidified sodium citrate. PAI-1 antigen level was determined using a two-site enzyme-linked immunosorbent assay (Biopool AB, Umea, Sweden). PAI-1 activity was measured with an assay based on the method of Veheijen et al., ${ }^{49}$ with standardized commercial kits (Biopool AB, Umea, Sweden). Because t-PA is bound by PAI-1, which inactivates it, the antigen level differs from the active level, which is determined only by t-PA unbound to PAI-1. Therefore, we measured only plasma t-PA activity, which was determined using an immunofunctional assay (Chromalize, Biopool AB, Umea, Sweden).

\section{Desmopressin test}

The capacity for acute stimulated t-PA release from vascular endothelium was assessed by the desmopressin test, ${ }^{39,40}$ which was performed after an overnight fast on the second-to-last day of the wash-out period and of each treatment period. An arterial polyethylene catheter was introduced percutaneously into the brachial artery of the non-dominant arm, and an indwelling cannula was introduced retrogradely into a deep antecubital vein of the same arm for venous blood sampling from the muscle vascular bed; the cannula was flushed with heparinized $\left(5 \mathrm{IU} \mathrm{ml}^{-1}\right)$ saline. After catheterization, patients rested for $30 \mathrm{~min}$ in the supine position. Then, a venous blood sample was obtained to evaluate baseline t-PA activity. Soon afterwards, the arterial desmopressin infusion began. Desmopressin was diluted in saline and was administered at a dose of $70 \mathrm{ng} \mathrm{min}^{-1}$ for $15 \mathrm{~min}$. The infusion was carried out at a constant rate of $1 \mathrm{ml} \mathrm{min}^{-1}$ by means of a syringe infusion pump. After 15 minutes, another venous blood sample was obtained to evaluate the t-PA activity response to desmopressin. The t-PA release experiments were not corrected for flow because previous data have demonstrated that the t-PA increase in response to desmopressin is independent of flow increase. ${ }^{39,40}$

\section{Evaluation of insulin sensitivity and glucose metabolism parameters}

Insulin sensitivity was assessed by euglycemic-hyperinsulinemic clamp, according to the technique of De Fronzo et al ${ }^{47}$ At $0900 \mathrm{~h}$, after the subjects had fasted for $12 \mathrm{~h}$ overnight, an intravenous catheter ( $18 \mathrm{~g}$ polyethylene cannula, Venflon, Viggo, Sweden) was placed in an antecubital vein for infusion of insulin and $20 \%$ glucose. A second catheter was inserted retrogradely into a wrist vein. The hand was heated (about $70^{\circ} \mathrm{C}$ ) in a thermoregulated box to arterialize venous blood within $20-40 \mathrm{~min}$. Plasma glucose was assessed at 5-10 min intervals during the clamp. A 10-min priming infusion of insulin (Humulin R, Lilly, Indianapolis, IN, USA) was administered at rate of $1 \mathrm{mU} \mathrm{min}^{-1}$ per $\mathrm{kg}$ for $2 \mathrm{~h}$, during which the plasma glucose concentration was held constant at the basal state $\left(95 \mathrm{mg} \mathrm{dl}^{-1}\right)$ by a variable infusion of exogenous glucose. The amount of glucose required for maintaining isoglycemia equals the whole-body disposal of glucose, provided that endogenous glucose production is essentially absent. During insulin infusion, normal fasting blood glucose level was maintained by adjusting the infusion rate of a $20 \%$ glucose solution. The amount of glucose taken up $\left(\mathrm{mg} \mathrm{min}^{-1}\right.$ per $\left.\mathrm{kg}\right)$ was calculated for each $10 \mathrm{~min}$ interval after the 
first $20 \mathrm{~min}$ of the clamp. Insulin sensitivity was calculated from the mean glucose uptake rate for the last $30 \mathrm{~min}$ of the clamp and expressed as the amount of glucose infused during that time (glucose infusion rate) in $\mathrm{mg} \min ^{-1}$ per $\mathrm{kg}$.

Blood glucose in the fasting state and during the glucose clamp was measured by the glucose oxidase method (Beckman Auto-Analyzer, Fullerton, CA, USA). Plasma insulin concentration was determined by radioimmunoassay.

\section{Statistical analysis}

The results were expressed as means \pm s.d. All data were analyzed by a split-plot method for analysis of variance; the data for PAI-1 were also analyzed for multiple comparisons by the Dunn-Šidak method for split-plot analysis of variance. Differences were considered significant when the $P$-value was less than 0.05 .

\section{RESULTS}

A total of 68 patients were screened between February and September 2008. At the end of the 2-week run-in period, 61 patients were randomized to receive imidapril $5 \mathrm{mg}(n=30)$ or candesartan $8 \mathrm{mg}$ $(n=31)$. Their main demographic and clinical characteristics are shown in Table 1. The two treatment groups were comparable in terms of age, sex, BMI, baseline sitting BP, total cholesterol, creatinine clearance, smoking habits, prevalence of left ventricular hypertrophy and of carotid intima-media thickness $>0.9$ and duration of hypertension. Five patients withdrew after randomization (two withdrew the informed consent and three complained of side-effects). A total of 56 patients, 28 in the imidapril group and 28 in the candesartan group, completed the study. At 8 weeks, $96.4 \%$ of patients in both treatment groups required dose titration.

The BP effects of the two agents are shown in Table 2. Both imidapril and candesartan significantly reduced sitting systolic BP $(-16$ and $-16.1 \mathrm{~mm} \mathrm{Hg}$, respectively; both $P<0.001 \mathrm{vs}$. baseline) and diastolic BP $(-12.6$ and $-12.2 \mathrm{~mm} \mathrm{Hg}$, respectively; both $P<0.001$ vs. baseline). The effects of the two drugs on BP were statistically similar and sustained for the duration of the study.

Treatment with either imidapril or candesartan decreased plasma PAI-1 antigen during the first 4 weeks; subsequently, only the effect of imidapril was sustained throughout the 12-week period, whereas in the candesartan group PAI-1 antigen returned to the baseline value at week 8 and significantly increased at 12 weeks (both were statistically

\section{Table 1 Subjects' characteristics}

\begin{tabular}{|c|c|c|}
\hline Parameters & Imidapril $(\mathrm{n}=30)$ & Candesartan $(\mathrm{n}=31)$ \\
\hline Age (years) & $53.0 \pm 10.8$ & $53.2 \pm 9.7$ \\
\hline Gender (Male/female) & $16 / 14$ & $16 / 15$ \\
\hline Male $>55$ years & 10 & 8 \\
\hline BMI $\left(\mathrm{kg} \mathrm{m}^{-2}\right)$ & $23.8 \pm 1.08$ & $23.9 \pm 1.07$ \\
\hline SBP (mm Hg) & $148.3 \pm 5.2$ & $148.8 \pm 4.8$ \\
\hline DBP (mm Hg) & $97.6 \pm 4.7$ & $98.8 \pm 4.2$ \\
\hline Total cholesterol (mg dl ${ }^{-1}$ ) & $207.6 \pm 30.5$ & $207.4 \pm 29.1$ \\
\hline Creatinine clearance & $103.7 \pm 11.1$ & $103.6 \pm 11$ \\
\hline Family history for CVD ( $n$ ) & 10 & 10 \\
\hline Smokers $(n)$ & 7 & 8 \\
\hline Patients with LVH $(n)$ & 4 & 3 \\
\hline Patients with CIMT $>0.9 \mathrm{~mm}(n)$ & 3 & 4 \\
\hline $\mathrm{FPG}(\mathrm{mg} \mathrm{dl}-1)$ & $88.9 \pm 8.8$ & $89.1 \pm 8.9$ \\
\hline FPI $\left(\mu \mid U^{-1}\right.$ per ml) & $9.4 \pm 2.7$ & $9.5 \pm 2.8$ \\
\hline Duration of hypertension (years) & $8.4 \pm 2.5$ & $8.6 \pm 2.4$ \\
\hline
\end{tabular}

Abbreviations: BMI, body mass index; CIMT, carotid intima-media thickness; CVD, cardiovascular disease; DBP, diastolic blood pressure; FPG, fasting plasma glucose; FPI, fasting plasma insulin; LVH, left ventricular hypertrophy; SBP, systolic blood pressure. different from baseline, $P<0.05$, and from imidapril, $P<0.01$ ) (Table 3) (Figure 1). Similar results were obtained for PAI-1 activity, which paralleled PAI-1 antigen behavior in both treatment groups (Table 3).

At the end of 12 weeks, t-PA activity had decreased from candesartan treatment (from $0.48 \pm 0.16$ to $0.43 \pm 0.14 \mathrm{IU} \mathrm{ml}^{-1}$ at week 12, $P<0.05$ ), but not from imidapril (from $0.47 \pm 0.15$ to

Table 2 Effect of treatment on blood pressure

\begin{tabular}{lcc}
\hline Time & Imidapril $(\mathrm{n}=28)$ & Candesartan $(\mathrm{n}=28)$ \\
\hline $\begin{array}{l}\text { Seated SBP mm Hg } \\
\text { Baseline }\end{array}$ & $148.4 \pm 4.8$ & $149.0 \pm 4.9$ \\
Week 1 & $144.1 \pm 5.1^{\star}$ & $145.6 \pm 4.9^{\star}$ \\
Week 2 & $142.8 \pm 4.8^{\dagger}$ & $143.5 \pm 4.9^{\dagger}$ \\
Week 4 & $136.8 \pm 4.9^{\ddagger}$ & $136.9 \pm 5.1^{\ddagger}$ \\
Week 8 & $133.6 \pm 4.2^{\ddagger}$ & $134.3 \pm 4.5^{\ddagger}$ \\
Week 12 & $132.4 \pm 4.1^{\ddagger}$ & $132.9 \pm 4.4^{\ddagger}$ \\
& & \\
Seated DBP mm Hg & & $98.5 \pm 4.0^{\ddagger}$ \\
Baseline & $98.7 \pm 4.4^{\ddagger}$ & $95.8 \pm 3.9^{\ddagger}$ \\
Week 1 & $95.4 \pm 4.5^{\star}$ & $94.1 \pm 3.8^{\dagger}$ \\
Week 2 & $94.8 \pm 4.3^{\dagger}$ & $88.9 \pm 4.1^{\ddagger}$ \\
Week 4 & $90.1 \pm 3.9^{\ddagger}$ & $87.1 \pm 3.2^{\ddagger}$ \\
Week 8 & $86.9 \pm 2.6^{\ddagger}$ & $86.3 \pm 3.2^{\ddagger}$ \\
Week 12 & $86.1 \pm 2.6^{\ddagger}$ &
\end{tabular}

Abbreviations: DBP, diastolic blood pressure; SBP, systolic blood pressure.

${ }^{*} P<0.05 ;{ }^{\dagger} P<0.01 ; \ddagger P<0.001$ vs. baseline.

Table 3 Effect of treatment on plasma PAI-1 antigen, PAI-1 activity and on t-PA activity

\begin{tabular}{|c|c|c|}
\hline Time & Imidapril $(\mathrm{n}=28)$ & Candesartan $(\mathrm{n}=28)$ \\
\hline \multicolumn{3}{|c|}{$P A l-1$ antigen $\left(\mathrm{ng} \mathrm{m}^{-1}\right)$} \\
\hline Baseline & $21.9 \pm 10.9$ & $21.0 \pm 11.2$ \\
\hline Week 1 & $15.2 \pm 7.1^{*}$ & $15.3 \pm 7.4^{*}$ \\
\hline Week 2 & $14.0 \pm 6.7^{*}$ & $17.1 \pm 8.1^{*}$ \\
\hline Week 4 & $15.5 \pm 6.5^{*}$ & $18.9 \pm 8.8$ \\
\hline Week 8 & $16.0 \pm 6.5^{*}$ & $21.3 \pm 9.4^{\dagger}$ \\
\hline Week 12 & $15.4 \pm 6.8^{*}$ & $24.5 \pm 10.6^{\star \S}$ \\
\hline \multicolumn{3}{|c|}{ PAl-1 activity $\left(I \cup \mathrm{ml}^{-1}\right)$} \\
\hline Baseline & $9.2 \pm 3.6$ & $9.7 \pm 3.8$ \\
\hline Week 1 & $6.8 \pm 2.4^{*}$ & $7.1 \pm 2.5^{*}$ \\
\hline Week 2 & $6.5 \pm 2.3^{*}$ & $8.1 \pm 3.1^{*}$ \\
\hline Week 4 & $6.7 \pm 2.5^{*}$ & $8.8 \pm 3.7$ \\
\hline Week 8 & $7.1 \pm 2.8^{*}$ & $9.8 \pm 4.1^{\dagger}$ \\
\hline Week 12 & $6.4 \pm 2.2^{*}$ & $11.5 \pm 4.6^{* \S}$ \\
\hline \multicolumn{3}{|c|}{$t-P A$ activity $\left(I \cup \mathrm{m}^{-1}\right)$} \\
\hline Baseline & $0.47 \pm 0.15$ & $0.48 \pm 0.16$ \\
\hline Week 1 & $0.50 \pm 0.13^{*}$ & $0.47 \pm 0.15$ \\
\hline Week 2 & $0.49 \pm 0.13^{*}$ & $0.46 \pm 0.15$ \\
\hline Week 4 & $0.47 \pm 0.12$ & $0.44 \pm 0.14^{*}$ \\
\hline Week 8 & $0.47 \pm 0.13$ & $0.43 \pm 0.14^{*}$ \\
\hline Week 12 & $0.49 \pm 0.14$ & $0.43 \pm 0.14^{*} \S$ \\
\hline
\end{tabular}

Abbreviations: PAl-1 antigen, plasminogen activator inhibitor-1 antigen; t-PA, tissue plasminogen activator. ${ }^{*} P<0.05$ vs. baseline; ${ }^{\dagger} P<0.02$ vs. imidapril; $¥ P<0.05$ vs. imidapril $\$ P<0.01$ vs. imidapril. 
$0.49 \pm 0.14 \mathrm{IU} \mathrm{ml}^{-1}, P<0.01$ vs. candesartan). The changes in t-PA activity over time are shown in Table 3 and Figure 1.

Desmopressin infusion markedly increased plasma t-PA activity to a similar extent in both treatment groups at the end of wash-out period $\left(+1.4 \mathrm{IU} \mathrm{ml}^{-1}\right.$ in the imidapril group and $+1.4 \mathrm{IU} \mathrm{ml}^{-1}$ in the
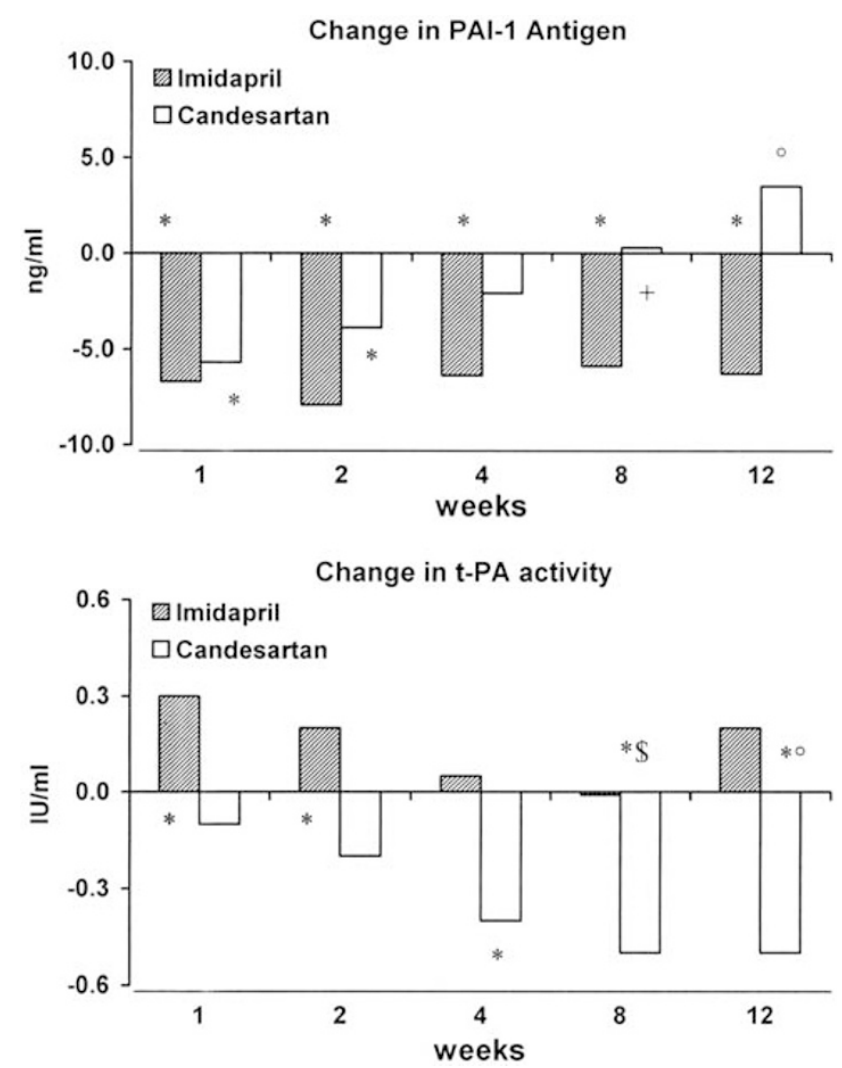

Figure 1 Changes in mean plasma PAI-1 antigen concentration and t-PA activity over time in response to treatment with imidapril or candesartan. ${ }^{*} P<0.05$ vs. baseline; ${ }^{+} P<0.02$ vs imidapril; ${ }^{\circ} P<0.01$ vs. imidapril $P<0.05$ vs. baseline; ${ }^{\$} P<0.05$ vs. imidapril; ${ }^{\circ} P<0.01$ vs. imidapril.

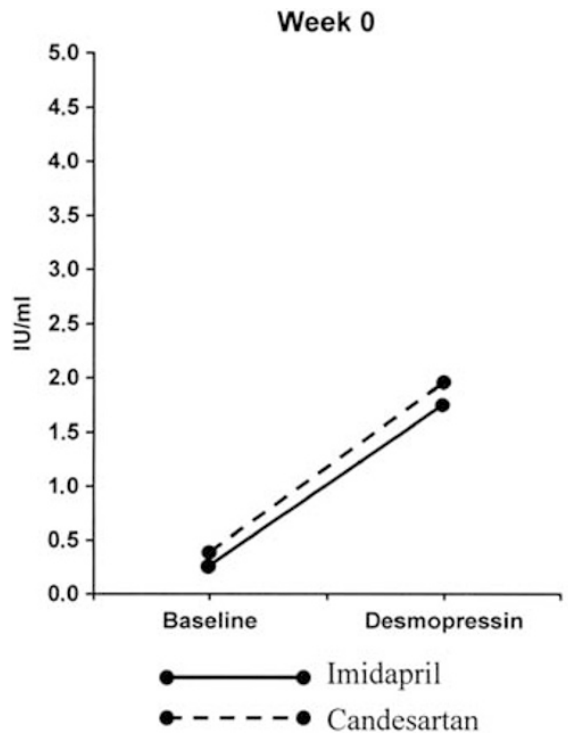

candesartan group). At the end of the treatment period, the t-PA activity response was further increased, but the increase was significantly greater in the imidapril group in which a threefold increase was observed $\left(+4.45 \mathrm{IU} \mathrm{ml}^{-1}\right)$, than in the candesartan group in which a twofold increase was observed $\left(+2.73 \mathrm{IU} \mathrm{ml}^{-1}, P<0.01\right.$ vs. imidapril) (Figure 2).

The effects on glucose metabolism are shown in Table 4, which provides data on the effects of therapy on fasting plasma glucose, fasting plasma insulin and insulin sensitivity. Neither drug significantly affected fasting plasma glucose or fasting plasma insulin, whereas glucose infusion rate, which is considered an index of insulin $\mathrm{s}$ ensitivity, was significantly increased by imidapril (by a mean of $1.1 \mathrm{mg} \mathrm{min}^{-1}$ per kg, $\left.P<0.01\right)$ but not by candesartan $\left(+0.1 \mathrm{mg} \mathrm{min}^{-1}\right.$ per $\mathrm{kg}, P=$ non significant).

No significant change in BMI was observed in either of the treatment groups.

\section{DISCUSSION}

The results of this study show that in normoweight patients with mild-to-moderate hypertension, despite a similar BP-lowering effect, imidapril and candesartan displayed different effects on the

Table 4 Effect of treatment on metabolic parameters

\begin{tabular}{lcc} 
Parameters & Imidapril $(\mathrm{n}=28)$ & Candesartan $(\mathrm{n}=28)$ \\
\hline $\begin{array}{l}\text { FPG }\left(\mathrm{mg} \mathrm{d}^{-1}\right) \\
\quad \text { Baseline }\end{array}$ & $88.9 \pm 8.8$ & $89.1 \pm 8.9$ \\
Week 12 & $88.4 \pm 8.7$ & $89.2 \pm 8.8$ \\
& & \\
FPI $\left(\mu / \mathrm{U}^{-1}\right.$ per $\left.\mathrm{ml}\right)$ & $9.4 \pm 2.7$ & $9.5 \pm 2.8$ \\
Baseline & $9.1 \pm 2.6$ & $9.4 \pm 2.7$ \\
Week 12 & & \\
GIR (mg min & \\
Baseline & & $5.2 \pm 1.8$ \\
Week 12 & $5.2 \pm 2.0$ & $5.3 \pm 1.7$ \\
\hline
\end{tabular}

Abbreviations: FPG, fasting plasma glucose; FPI, fasting plasma insulin; GIR, glucose infusion rate. ${ }^{*} P<0.01$ vs. baseline; ${ }^{\dagger} P<0.01$ vs. candesartan.

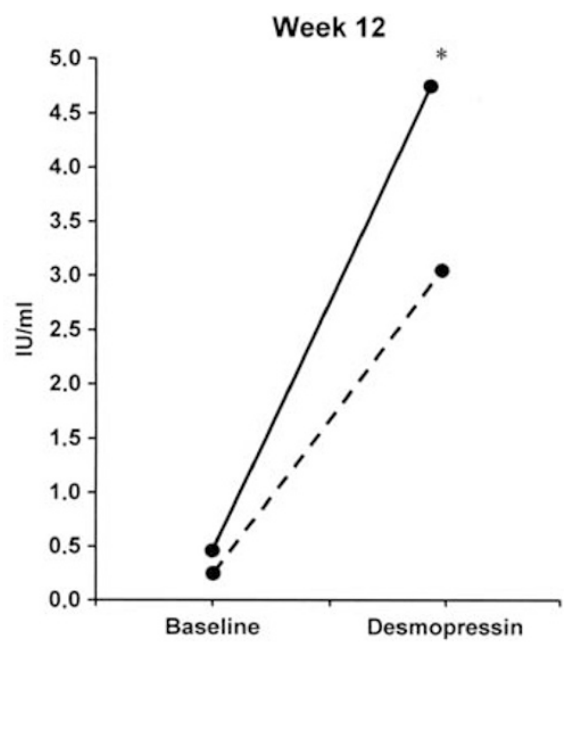

Figure 2 Plasma t-PA activity in response to desmopressin infusion at the end of the wash-out period and at the end of each treatment period. ${ }^{*} P<0.01$ vs. Candesartan. 
fibrinolytic balance. In fact, after 12 weeks of treatment, imidapril significantly reduced PAI-1 antigen level and activity without affecting plasma active t-PA level, whereas candesartan did not change PAI-1 but did decrease plasma active t-PA. In agreement with some previous observations, ${ }^{50}$ when considering the effect of ACE inhibition and Ang II AT1 receptor blockade on plasma PAI-1 antigen over time, we observed a different time courses of the effects: short-term treatment with either imidapril or candesartan significantly reduced plasma PAI-1 antigen, whereas in the long term only imidapril decreased PAI-1 antigen. Similar results were obtained for plasma PAI-1 activity. Different time courses of effects of ACE inhibition and Ang II AT1 receptor blockade on t-PA concentrations were also observed, because t-PA level decreased significantly over time in candesartan but not in imidapril treatment.

The different effects of imidapril and candesartan on the fibrinolytic balance observed in the present study were not caused by a difference in BP-lowering effects because the extent of BP decrease was similar in both treatment groups. As obesity is one of the factors that activate renin angiotensin system (RAS), only patients with normal body weight were included in the study to avoid the influence of body weight on the fibrinolytic process. ${ }^{51}$ No significant change in BMI was observed throughout treatment with either imidapril or candesartan, so the observed modifications in the fibrinolytic parameters were not related to changes in body weight.

One possible explanation for the dissimilar effects of imidapril and candesartan on the fibrinolytic balance might be their different effects on kinin metabolism. Unlike ARBs that do not affect the metabolism of bradykinin, ACE-Is may exert a beneficial effect on fibrinolysis by blocking the degradation of bradykinin, which stimulates t-PA synthesis and release from endothelial cells through a bradykinin type-2 receptor-dependent pathway. ${ }^{10,11}$

The dissimilar effects of imidapril and candesartan on PAI-1 could have been due in part to increased PAI-1 expression by the hexapeptide Ang II metabolite Ang IV and to stimulation of AT4 receptor, as reported in vitro in human endothelial cells. ${ }^{52}$ These effects could have increased PAI-1 antigen concentration after short-term AT1 receptor blockade and after 2 week AT1 blockade, when AT4 receptors may be upregulated. ${ }^{53}$ This mechanism is difficult to determine in a clinical setting and remains undetermined in the present study. Another explanation is that Ang II-induced PAI-1 expression is mediated by AT1 receptors, and the brevity of the effect of candesartan might then depend on AT1 receptor upregulation..$^{50}$ More specifically, after PAI- 1 was decreased in weeks 1 and 2 because of AT1 blockade, AT1 was upregulated and PAI-1 was increased. It has also been hypothesized that the different time courses of the effects of ACE-I and ARB on PAI-1 level result from differences in the duration of suppression of tissue Ang II, which is suppressed by ACE-I and not suppressed by ARB. ${ }^{50}$

Furthermore, the dissimilar effects on fibrinolysis of imidapril and candesartan might depend on their different effects on insulin sensitivity, whose relationship with PAI-1 level, observed in crosssectional studies, has been confirmed by interventional studies aimed at reducing insulin resistance, which have demonstrated a parallel decrease in plasma insulin and PAI-1 levels. ${ }^{45,46,54}$ In the present study, imidapril significantly increased insulin sensitivity, as assessed by euglycemic-hyperinsulinemic clamp, whereas candesartan did not. These findings, which are in agreement with previous observations by ourselves and other authors, ${ }^{35,55-57}$ besides providing another possible explanation for the different effects of the two drugs on the fibrinolytic balance, also suggest that mechanisms other than Ang II inhibition, such as the increase in endogenous kinins because of ACE inhibition, might be responsible for the observed different influences of imidapril and candesartan on insulin sensitivity.

Systemic administration of desmopressin increases t-PA activity. ${ }^{39,40}$ Although the mechanisms behind this response are not fully defined, it has commonly been assumed that desmopressin induces endothelial release of t-PA. ${ }^{39,40}$ Therefore, in the present study the capacity for acute t-PA release from vascular endothelium before and after treatment with imidapril or candesartan was evaluated through desmopressin infusion as an index of endothelial function. We observed: (1) a greater increase in t-PA activity in response to desmopressin after 12-weeks treatment with both imidapril and candesartan than compared with baseline; and (2) this increase was significantly more pronounced with imidapril than compared with candesartan. These findings suggest that antihypertensive therapy with both the drugs improved the capacity for acute t-PA release, probably through an improvement of endothelial function. The reduction in the vascular shear stress resulting from the hypotensive action of both imidapril and candesartan might partly explain such an improvement compared with baseline. However, the different influences of ACE inhibition and Ang II AT1 receptor blockade on bradykinin metabolism and kininmediated t-PA release from human endothelium might be one possible explanation for the observed greater improvement with imidapril.

Although it is accepted that imidapril is a selective ACE-I and candesartan is an ARB, the selectivity of the compounds is generally relative, and the potential actions associated with the compound themselves cannot be completely excluded, which may constitute a limitation of this study. Further studies with other agents are needed to generalize the current investigation to the characteristics of these classes of agents.

The results of this study show that in normoweight hypertensive patients, 12-weeks treatment with the ACE-I imidapril or the ARB candesartan, despite similar BP-lowering effects, displayed different effects on the fibrinolytic balance and insulin sensitivity: imidapril but not candesartan significantly improved them. Different time courses of the effects of the two drugs on the fibrinolytic parameters and a significantly greater t-PA activity increase in response to desmopressin with imidapril were also observed. These findings imply that mechanisms other than direct inhibition of Ang II-mediated signaling, such as the kinin-mediated effects on insulin sensitivity and bradykininstimulated t-PA release from human endothelium, may have crucial roles in the differential effects of imidapril and candesartan on the fibrinolytic balance, whereas Ang II signaling could also contribute to the difference.

Many other studies have demonstrated the beneficial effects of ACE-I on prothrombotic state, ${ }^{12-17}$ as well as insulin sensitivity ${ }^{58-60}$ in addition to their efficacy in normalizing elevated BP, which might result in better cardiovascular protection by these drugs. In this regard, a meta-analysis of clinical studies has shown that ACE-I but not ARB may reduce the risk of major coronary disease events. ${ }^{61}$ Although various underlying mechanisms might give rise to this significant difference, the positive effects of ACE-Is on the fibrinolytic balance might contribute to the greater reduction in myocardial infarction rate achieved in clinical trials with these drugs.

1 Brown NJ, Agirbasli MA, Williams GH, Litchfield WR, Vaughan DE. Effect of activation and inhibition of the renin-angiotensin system on plasma PAI-1. Hypertension 1998; 32: 965-971.

2 Vaughan DE. Angiotensin, fibrinolysis and vascular homeostasis. Am J Cardiol 2001; 87(Suppl): 18C-24C. 
3 Ferrario CM, Strawn WB. Role of the renin-angiotensin-aldosterone system and pro-inflammatory mediators in cardiovascular disease. Am J Cardiol 2006; 98 : $121-128$.

4 Feener EP, Nortrup JM, Aiello LP, King GL. Angiotensin II induces plasminogen activator inhibitor 1 and 2 expression in vascular endothelial and smooth muscle cells. J Clin Invest 1995; 95: 1353-1362.

5 Nishimura H, Tsuji H, Masuda H, Nakagawa K, Nakahara Y, Kitamura H, Kasahara T, Sugano T, Yoshizumi M, Sawada S, Nakagawa M. Angiotensin II increases plasminogen activator inhibitor-1 and tissue factor mRNA expression without changing that of tissue factor pathway inhibitor in cultured rat aortic endothelial cells. Thromb Haemost 1997 ; 77: 1189-1195.

6 Olson JA, Shiverick KT, Ogilvie S, Buhi WC, Raizada MK. Angiotensin II induces secretion of plasminogen activator inhibitor 1 and a tissue metalloprotease inhibitor-related protein from rat brain astrocytes. Neurobiology 1991; 88: 1928-1932.

7 Van Leeuwen RT, Kol A, Andreotti F, Kluft C, Maseri A, Sperti G. Angiotensin II increases plasminogen activator inhibitor type 1 and tissue type plasminogen activator messenger RNA in cultured rat aortic smooth muscle cells. Circulation 1994; 90: 362-368.

8 Ridker PM, Gaboury CL, Conlin PR, Seely EW, Williams GH, Vaughan DE. Stimulation of plasminogen activator inhibitor in vivo by infusion of angiotensin II: evidence of a potential interaction between the renin-angiotensin-system and fibrinolytic function. Circulation 1993; 87: 1969-1973.

9 Brown NJ, Kim KS, Chen YQ, Blevins LS, Nadeau JH, Meranze SG, Vaughan DE. Synergistic effect of adrenal steroids and angiotensin II on plasminogen activator inhibitor 1 production. J Clin Endocrinol Metab 2000; 85: 336-344.

10 Emeis JJ, Tranquille N. On the role of bradykinin in secretion from vascular endothelial cells. Agents Actions 1992; 38: 285-292.

11 Brown NJ, Gainer JV, Stein CM, Vaughan DE. Bradykinin stimulate tissue plasminogen activator release in human vasculature. Hypertension 1999; 33: 1431-1435.

12 Wright RA, Flapan AD, Alberti KG, Ludlam CA, Fox KA. Effects of captopril therapy on endogenous fibrinolysis in men with recent, uncomplicated myocardial infarction. $J A m$ Coll Cardiol 1994; 24: 67-73.

13 Vaughan DE, Rouleau JL, Ridker PM, Arnold JM, Menapace FJ, Pfeffer MA. Effects of ramipril on plasma fibrinolytic balance in patients with acute anterior myocardial infarction: HEART Study investigators. Circulation 1997; 96: $442-447$.

14 Soejima H, Ogawa H, Yasue H, Suefuji H, Kaikita K, Nishiyama K. Effects of imidapril therapy on endogenous fibrinolysis in patients with recent myocardial infarction. Clin Cardiol 1997; 20: 441-445.

15 Sayer JW, Gutteridge C, Syndercombe-Court D, Wilkinson P, Timmis AD. Circadian activity of the endogenous fibrinolytic system in stable coronary artery disease: effects of beta-adrenoreceptor blockers and angiotensin converting enzyme inhibitors. J Am Coll Cardiol 1998; 32: 1962-1968.

16 Sakata K, Shirotani M, Yoshida H, Urano T, Takada Y, Takada A. Differential effects of enalapril and nitrendipine on the fibrinolytic system in essential hypertension. $\mathrm{Am}$ Heart J 1999; 137: 1094-1099.

17 Fogari R, Preti P, Lazzari P, Corradi L, Zoppi A, Fogari E, Mugellini A. Effect of benazepril amlodipine combination on fibrinolysis in hypertensive diabetic patients. Eur J Clin Pharmacol 2003; 59: 271-275.

18 Vaughan DE, Rouleau JI, Pfeffer MA. Role of the fibrinolytic system in preventing myocardial infarction. Eur Heart J 1995; 16(Suppl K): 31-36.

19 Matsumoto T, Minai K, Horie H, Ohira N, Takashima H, Tarutani Y, Yasuda Y, Ozawa T, Matsuo S, Kinoshita M, Horie M. Angiotensin-converting enzyme inhibition but not angiotensin II type 1 receptor antagonism augments coronary release of tissue plasminogen activator in hypertensive patients. J Am Coll Cardiol 2003; 41: 1373-1379.

20 Janson JH, Borman K, Nilsson TK. Enalapril related changes in the fibrinolytic system in survivors of myocardial infarction. Eur J Clin Pharmacol 1993; 44: 485-488.

21 Lottermoser K, Wostmann B, Weisser B, Hertfelder HJ, Schmitz U, Vetter H, Dusing R. Effects of captopril on fibrinolytic function in healthy humans. Eur J Med Res 1999; 4: 31-34.

22 Trifiletti A, Barbera N, Scamardi R, Bagnato L, Pizzoleo MA, Nevoso A, Lasco A, Pedullà $M$, Frisina N. Effects of medium-term antihypertensive therapy on hemostatic parameters in patients with essential hypertension. Haemostasis 1997; 27: 35-38.

23 Alessi MC, Juhan-Vague I, Declerck PJ, Collen D. Molecular forms of plasminogen activator inhibitor 1 (PAI-1) and tissue type plasminogen activator (t-PA) in human plasma. Thromb Res 1991; 62: 275-285.

24 Hrafnkelsdottir T, Gudnason T, Wall U, Jern C, Jern S. Regulation of local availability of active tissue-type plasminogen activator in vivo in man. J Thromb Haemost 2004; 2: 1960-1968.

25 Giannarelli C, Virdis A, De Negri F, Duranti E, Magagna A, Ghiadoni L, Salvetti A, Taddei $\mathrm{S}$. Tissue-type plasminogen activator release in healthy subjects and hypertensive patients. Relationship with beta-adrenergic receptors and the nitric oxide pathway. Hypertension 2008; 52: 314-321.

26 Lottermoser K, Hertfelder HH, Vetter H, Dusing R. Fibrinolytic function in diureticinduced volume depletion. Am J Hypertens 2000; 13: 359-363.

27 Erdem Y, Usalan C, Haznedarodlu IC, Altun B, Arici M, Yasavul U, Turgan C, Cağlar S. Effects of angiotensin converting enzyme and angiotensin II receptor inhibition on impaired fibrinolysis in systemic hypertension. Am J Hypertens 1999; 11: 1071-1076.
28 Liu L, Zhao SP, Zhou HN, Li QZ, Li Jx. Effect of fluvastatin and valsartan, alone and in combination, on post-prandial vascular inflammation and fibrinolytic activity in patients with essential hypertension. J Cardiovasc Pharmacol 2007; 50: 50-55.

29 Seljeflot I, Moan A, Kjeldsen S, Sandvik E, Arnesen H. Effect of angiotensin II receptor blockade on fibrinolysis during acute hyperinsulinemia in patients with essential hypertension. Hypertension 1996; 27: 1299-1304.

30 Fogari R, Zoppi A, Malamani G, Marasi G, Pesce RM, Banderali A, Mugellini A. Effects of four angiotensin II-receptor antagonists on fibrinolysis in post-menopausal women with hypertension. Curr Ther Res 2001; 62: 68-78.

31 Skurk T, Lee YM, Nicuta-Rolfs TO, Haastert B, Wirth A, Hauner H. Effect of the angiotensin II receptor blocker candesartan on fibrinolysis in patients with mild hypertension. Diabetes Obes Metab 2004; 6: 56-62.

32 Lin TH, Voon WC, Yen HW, Huang CH, Su HM, Lai WT, Sheu SH. Lercanidipine and losartan effects on blood pressure and fibrinolytic parameters. Kaohsiung J Med Sci 2006; 22: 177-183.

33 Brown NJ, Agirbasli M, Vaughan DE. Comparative effect of angiotensin converting enzyme inhibition and angiotensin II type 1 receptor antagonism on plasma fibrinolytic balance in humans. Hypertension 1999; 34: 285-290.

34 Goodfield NE, Newby DE, Ludlam CA, Flapan AD. Effects of acute angiotensin II type 1 receptor antagonism and angiotensin converting enzyme inhibition on plasma fibrinolytic parameters in patients with heart failure. Circulation 1999; 99: 2983-2985.

35 Fogari R, Zoppi A, Preti P, Fogari E, Malamani G, Mugellini A. Differential effects of ACE-inhibition and angiotensin II antagonism on fibrinolysis and insulin sensitivity in hypertensive post-menopausal women. Am J Hypertens 2001; 14: 921-926.

36 Fogari R, Mugellini A, Zoppi A, Corradi L, Preti P, Lazzari P, Derosa G. Losartan and perindopril effects on plasma plasminogen activator inhibitor-1 and fibrinogen in hypertensive type 2 diabetics. Am J Hypertens 2002; 15: 316-320.

37 Paterna S, Di Garbo V, Avellone G, Di Pasquale P, Cacia A, Tuttolomondo A, Follone G, Cardinale A, Maniscalchi T, Licata G. Effects of losartan and delapril on the fibrinolytic system in patients with mild to moderate hypertension. Clin Drug Invest 2003; 23: 717-724.

38 Hirschl MM, Bur A, Woisetschlaeger C, Derhaschnig U, Laggner AN. Effects of candesartan and lisinopril on the fibrinolytic system in hypertensive patients. J Clin Hypertens 2007; 9: 430-435.

39 Brummer EJP, Baret-Bergshoeff MM, Allen RA, Schicht I, Bertina RM, Schalekamp MADH. The use of desmopressin acetate (DDAVP) as a test of the fibrinolytic capacity. Analysis of responders and non responders. Thromb Haemost 1982; 48: 156.

40 Wall U, Jern S, Tengborn L, Jern C. Evidence of local mechanism for desmopressininduced tissue-type plasminogen activator release in human forearm. Blood 1998; 91 : 529-537.

41 Alessi MC, Juhan-Vague I, Kooistra T, Declerck PJ, Collen D. Insulin stimulates the synthesis of plasminogen activator inhibitor by the human hepatocellular cell line HepG2. Thromb Haemost 1988; 60: 491-494.

42 Nordt TK, Klassen KJ, Schneider DJ, Sobel BE. Augmentation of synthesis of plasminogen activator inhibitor type 1 in arterial endothelial cells by glucose and its implications for local fibrinolysis. Arterioscler Thromb 1993; 13: 1822-1828.

43 Nordt TK, Sawa H, Fujii S, Sobel BE. Induction of plasminogen activator inhibitor type 1(PAI-1) by proinsulin and insulin in vivo. Circulation 1995; 91: 764-770.

44 Juan-Vague I, Alessi MC, Vague P. Increased plasma plasminogen activator inhibitor 1 levels: a possible link between insulin resistance and atherothrombosis. Diabetologia 1991; 34: 457-462.

45 Jeng JR, Sheu WHH, Jeng SC, Huang SH, Shieh SM. Impaired fibrinolysis and insulin resistance in patients with hypertension. Am J Hypertens 1996; 9: 484-490.

46 Juhan Vague I, Roul C, Alessi MC, Ardissone JP, Heim M, Vague P. Increased plasminogen activator inhibitor activity in non-insulin dependent diabetic patients: Relationship with plasma insulin. Thromb Haemost 1989; 61: 370-373.

47 De Fronzo RA, Tobin JA, Andres B. Glucose clamp technique, a method for quantifying insulin secretion and resistance. Am J Physiol 1979; 237: 214-223.

48 Hansson L, Hedner T, Dahlof B. Prospective, randomized, open, blinded end-point (PROBE) study: a novel design for intervention trials. Blood Press 1992; 1: $113-114$

49 Verheijen JH, Chang GTC, Kluff C. Evidence for the occurrence of a fast acting inhibitor of tissue-type plasminogen activator in plasma. Thromb Haemost 1984; 51: 392-395.

50 Brown NJ, Kumar S, Painter CA, Vaughan DE. ACE inhibition versus angiotensin type 1 receptor antagonism. Differential effects on PAI-1 over time. Hypertension 2002; 40: 859-865.

51 Folsom AR, Quamhieh DT, Wing RR, Jeffery RW, Stinson VL, Kuller LH, Wu KK. Impact of weight loss on plasminogen activator inhibitor (PAI-1), factor VII and other hemostatic factors in moderately overweight adults. Arterioscler Thromb Vasc Biol 1993; 13: 162-169.

52 Kerins DM, Hao Q, Vaughan DE. Angiotensin induction of PAI-1 expression in endothelial cells is mediated by the hexapeptide angiotensin IV. J Clin Invest 1995; 96: 2515-2520.

53 Moeller I, Clune EF, Fennessy PA, Bingley JA, Albiston AL, Mendelsohn FA, Chai SY. Up-regulation of AT4 receptor levels in carotid arteries following balloon injury. Regul Pept 1999; 83: 25-30. 
54 Vague P, Juhan Vague I, Aless MC, Badier C, Valadier J. Metformin decreases the high plasminogen activator inhibitor capacity, plasma insulin and triglycerides levels in nondiabetic obese subjects. Thromb Haemost 1987; 57: 326-328.

55 Fogari R, Zoppi A, Lazzari P, Preti P, Mugellini A, Corradi L, Lusardi P. ACE inhibition but not angiotensin II antagonism reduces plasma fibrinogen and insulin resistance in overweight hypertensive patients. J Cardiovasc Pharmacol 1998; 32 : 616-620.

56 Moan A, Hoieggen A, Seljieflot I, Risanger T, Aenesen H, Kjeldsen SE. The effect of angiotensin II receptor antagonism with losartan on glucose metabolism and insulin sensitivity. J Hypertens 1996; 14: 1093-1097.

57 Laakso M, Karjalainen L, Lempiainen-Kuosa P. Effects of losartan on insulin sensitivity in hypertensive subjects. Hypertension 1996; 28: 392-396.
58 Lithell H, Pollare T, Berne C. Insulin sensitivity in newly detected hypertensive patients:influence of captopril and other antihypertensive agents on insulin sensitivity and related biological parameters. J Cardiovasc Pharmacol 1990; 15(Suppl 5): S46-S52.

59 Torlone E, Bolli GB. Angiotensin converting enzyme inhibition improves insulin sensitivity in type II diabetes mellitus. Arch Gerontol Geriatr 1991; 3(Suppl 2): 287-290.

60 Falkner B, Canessa M, Anzalone D. Effect of angiotensin converting enzyme inhibitor (lisinopril) on insulin sensitivity and sodium transport in mild hypertension. $A m ~ J$ Hypertens 1995; 8: 454-460.

61 Blood Pressure Lowering Treatment Trialist's Collaboration. Pressure-dependent and independent effects of agents that inhibit the renin-angiotensin system. $J$ Hypertens 2007; 25: 951-958 